\title{
Calcium Transient and Sodium-Calcium Exchange Current in Human versus Rabbit Sinoatrial Node Pacemaker Cells
}

\author{
Arie O. Verkerk, ${ }^{1}$ Marcel M. G. J. van Borren, ${ }^{2}$ and Ronald Wilders ${ }^{1}$ \\ ${ }^{1}$ Department of Anatomy, Embryology and Physiology, Academic Medical Center, University of Amsterdam, Meibergdreef 15, \\ 1105 AZ Amsterdam, The Netherlands \\ ${ }^{2}$ Laboratory of Clinical Chemistry and Hematology, Jeroen Bosch Hospital, Henri Dunantstraat 1, \\ 5223 GZ 's-Hertogenbosch, The Netherlands
}

Correspondence should be addressed to Ronald Wilders; r.wilders@amc.uva.nl

Received 11 January 2013; Accepted 7 February 2013

Academic Editors: Y. Du and Y. Wang

Copyright (C) 2013 Arie O. Verkerk et al. This is an open access article distributed under the Creative Commons Attribution License, which permits unrestricted use, distribution, and reproduction in any medium, provided the original work is properly cited.

\begin{abstract}
There is an ongoing debate on the mechanism underlying the pacemaker activity of sinoatrial node (SAN) cells, focusing on the relative importance of the "membrane clock" and the "Ca ${ }^{2+}$ clock" in the generation of the small net membrane current that depolarizes the cell towards the action potential threshold. Specifically, the debate centers around the question whether the membrane clock-driven hyperpolarization-activated current, $I_{f}$, which is also known as the "funny current" or "pacemaker current," or the $\mathrm{Ca}^{2+}$ clock-driven sodium-calcium exchange current, $I_{\mathrm{NaCa}}$, is the main contributor to diastolic depolarization. In our contribution to this journal's "Special Issue on Cardiac Electrophysiology," we present a numerical reconstruction of $I_{f}$ and $I_{\mathrm{NaCa}}$ in isolated rabbit and human SAN pacemaker cells based on experimental data on action potentials, $I_{f}$, and intracellular calcium concentration $\left(\left[\mathrm{Ca}^{2+}\right]_{i}\right)$ that we have acquired from these cells. The human SAN pacemaker cells have a smaller $I_{f}$, a weaker $\left[\mathrm{Ca}^{2+}\right]_{i}$ transient, and a smaller $I_{\mathrm{NaCa}}$ than the rabbit cells. However, when compared to the diastolic net membrane current, $I_{\mathrm{NaCa}}$ is of similar size in human and rabbit SAN pacemaker cells, whereas $I_{f}$ is smaller in human than in rabbit cells.
\end{abstract}

\section{Introduction}

Animal studies have demonstrated that pacemaker activity of the sinoatrial node (SAN) is controlled by a complex system of "clocks" composed of voltage-dependent sarcolemmal currents-designated the "membrane clock," "voltage clock," or "ion channel clock" - and tightly coupled sarcoplasmic reticulum (SR) $\mathrm{Ca}^{2+}$ cycling molecules together with the electrogenic sodium-calcium exchanger, named the " $\mathrm{Ca}^{2+}$ clock" $[1,2]$. There is an ongoing debate on the relative importance of the "membrane clock" and the " $\mathrm{Ca}^{2+}$ clock" in the generation of the small net membrane current underlying the spontaneous diastolic depolarization that drives the cell towards its action potential threshold [3-7]. This debate centers around the contribution of the hyperpolarizationactivated current $I_{f}$, also known as "funny current" or "pacemaker current," as a member of the membrane clock, and the sodium-calcium exchange current $I_{\mathrm{NaCa}}$, resulting from the electrogenic sodium-calcium exchange process and thus driven by the $\mathrm{Ca}^{2+}$ clock.

In contrast with the data collected in animal studies, the mechanism of SAN pacemaker activity in man is virtually unexplored. In a comprehensive study, Chandler et al. [8] characterized the "molecular architecture" of the human SAN based on messenger RNA (mRNA) levels of 120 ion channels and related proteins, and they concluded that the expression pattern was appropriate to explain pacemaking. They observed a prominent expression of $\mathrm{HCN} 4$ and, to a lesser extent, HCN1, which are both subunits of the $I_{f}$ channel. We actually recorded $I_{f}$ in voltage clamp experiments on single pacemaker cells isolated from the SAN of a patient who underwent SAN excision [9]. From these cells, we also acquired spontaneous action potentials, which showed a clear diastolic depolarization phase resulting in an intrinsic cycle length of $\approx 830 \mathrm{~ms}$ ( 72 beats/min). In addition, our voltage clamp experiments revealed the presence of a fast large 
inward current with characteristics of the $\mathrm{Na}^{+}$current, $I_{\mathrm{Na}}$ [10].

Clinical data also point to a role for $I_{f}$ and $I_{\mathrm{Na}}$ in human SAN pacemaker activity. Mutations in HCN4 and SCN5A, encoding pore-forming subunits of the $I_{f}$ and $I_{\mathrm{Na}}$ channel, respectively, have been linked to familial sick sinus syndrome (see $[11,12]$ and primary references cited therein), thus suggesting that $I_{f}$ and $I_{\mathrm{Na}}$ indeed contribute to human SAN pacemaker activity. A further clinical indication regarding the role of a specific ion current in human SAN pacemaker activity involves the slowly activating delayed rectifier $\mathrm{K}^{+}$ current $\left(I_{\mathrm{Ks}}\right)$ and comes from patients who suffer from the long-QT syndrome type 1 and carry a loss-of-function mutation in the KCNQ1 (KvLQT1) gene, encoding the poreforming $\alpha$-subunit of the $I_{\mathrm{Ks}}$ channel. These patients have close-to-normal heart rates in rest [13], but their ability to increase heart rate during exercise is seriously impaired [14].

The aforementioned experimental and clinical observations all point to a role for important components of the "membrane clock" in human SAN pacemaker activity. There are also some clinical data in support of a contribution of the " $\mathrm{Ca}^{2+}$ clock" through patients with catecholaminergic polymorphic ventricular tachycardia (CPVT), who have an impaired $\mathrm{Ca}^{2+}$ clock due to mutations in the RYR2 gene (CPVT1) or the CASQ2 gene (CPVT2), encoding the cardiac ryanodine receptor isoform 2 (RyR2, responsible for $\mathrm{Ca}^{2+}$ release from the SR) and the cardiac calsequestrin isoform 2 protein (calsequestrin-2, responsible for calcium buffering in the SR), respectively [15]. Leenhardt et al. [16] observed a marked sinus bradycardia in a group of 21 nongenotyped CPVT patients. Sumitomo et al. [17] also reported sinus bradycardia in their group of 29 nongenotyped CPVT patients. At the time of the reports by Leenhardt et al. [16] and Sumitomo et al. [17], CPVT had not yet been associated with the RYR2 and CASQ2 genes. More recently, Postma et al. [18, 19] found a marked sinus bradycardia in both CPVT1 [18] and CPVT2 [19] patients.

Chandler et al. [8] observed various $\mathrm{Ca}^{2+}$-handling proteins in the human SAN, albeit less abundant than in the surrounding right atrium, including NCX1 (responsible for sodium-calcium exchange in the heart), RyR2, and SERCA2a (responsible for $\mathrm{Ca}^{2+}$ uptake by the SR). They constructed a mathematical model of a human SAN cell by modification of the Courtemanche et al. [20] model of a human atrial myocyte, scaling ion current densities on the basis of the relative mRNA expression level in SAN and atrium and introducing the T-type $\mathrm{Ca}^{2+}$ current and $I_{f}$. Specifically, $I_{\mathrm{NaCa}}$ was scaled down to $74 \%$ of its value in the Courtemanche et al. [20] model. Recently, Allah et al. [21] published a study in which they used the same experimental approach as Chandler et al. [8] to determine the expression of ion channels and $\mathrm{Ca}^{2+}$ handling proteins in the SAN, right atrium, and left ventricle of the neonate and adult rabbit. From their Figure 6 [21], it appears that the mRNA expression level of the NCX1 gene in the adult rabbit SAN is $\approx 78 \%$ and $\approx 69 \%$ of that in right atrium and left ventricle, respectively.
When we recorded action potentials from isolated human SAN pacemaker cells and carried out voltage clamp experiments [9], we also acquired some data on the intracellular free $\mathrm{Ca}^{2+}$ concentration $\left(\left[\mathrm{Ca}^{2+}\right]_{i}\right)$ of human SAN pacemaker cells using the fluorescent $\mathrm{Ca}^{2+}$ indicator Indo-1. In the present study, we use these thus far unpublished experimental data in a numerical reconstruction of $I_{\mathrm{NaCa}}$ in a human SAN pacemaker cell. The thus obtained $I_{\mathrm{NaCa}}$ is compared to the net membrane current $\left(I_{\text {net }}\right)$ and to $I_{f}$, which are also obtained through a numerical reconstruction. In addition, we present data on $I_{f}, I_{\mathrm{NaCa}}$, and $I_{\text {net }}$ in rabbit SAN pacemaker cells, thus allowing a comparison of these currents between rabbit and human SAN pacemaker cells.

\section{Materials and Methods}

2.1. Cell Preparations. Single SAN cells were isolated by an enzymatic dissociation procedure as described previously [22] from New Zealand White rabbits and from a patient who underwent SAN excision because of inappropriate sinus tachycardias originating from the SAN region (see [9] for clinical details). In either case, cells were stored at room temperature for at least $45 \mathrm{~min}$ in modified Kraft-Brühe (KB) solution before they were put into a recording chamber on the stage of an inverted microscope and superfused with modified Tyrode's solution at $36 \pm 0.2^{\circ} \mathrm{C}$. $\mathrm{KB}$ solution contained (in mM) $\mathrm{KCl} 85, \mathrm{~K}_{2} \mathrm{HPO}_{4} 30, \mathrm{MgSO}_{4} 5.0$, glucose 20, pyruvic acid 5.0, creatine 5.0, taurine $30, \beta$-hydroxybutyric acid 5.0, succinic acid 5.0, BSA 1\%, and $\mathrm{Na}_{2}$ ATP 2.0; $\mathrm{pH}$ was set to 6.9 with $\mathrm{KOH}$. Modified Tyrode's solution contained (in $\mathrm{mM}$ ) $\mathrm{NaCl} 140, \mathrm{KCl} 5.4, \mathrm{CaCl}_{2} 1.8, \mathrm{MgCl}_{2} 1.0$, glucose 5.5, and HEPES 5.0; $\mathrm{pH}$ was set to 7.4 with $\mathrm{NaOH}$. Spindle and elongated spindle-like cells displaying regular contractions were selected for measurements.

2.2. Cytosolic $\mathrm{Ca}^{2+}$ Measurements. Cytosolic $\mathrm{Ca}^{2+}$ concentration $\left(\left[\mathrm{Ca}^{2+}\right]_{i}\right)$ was measured in Indo-1 loaded cells as described previously [23]. In brief, cells were loaded with $5 \mu \mathrm{M}$ of the fluorescent dye Indo-1-AM (Molecular Probes, Eugene, OR, USA) for $10 \mathrm{~min}$ at room temperature in $\mathrm{KB}$ solution and subsequently superfused with modified Tyrode's solution for $15 \mathrm{~min}$ at $36 \pm 0.2^{\circ} \mathrm{C}$ to remove excess indicator and allow full deesterification. A rectangular adjustable slit was used to select a single cell and to reduce background fluorescence. Dual wavelength emission of Indo-1 upon excitation at $340 \mathrm{~nm}$ was recorded at $405-440$ and 505$540 \mathrm{~nm}$ using photomultiplier tubes, and, after correction for background fluorescence, free $\left[\mathrm{Ca}^{2+}\right]_{i}$ was calculated as described by van Borren et al. [23].

$\left[\mathrm{Ca}^{2+}\right]_{i}$ transients were characterized by the minimum diastolic $\left[\mathrm{Ca}^{2+}\right]_{i}$ (MDC), their amplitude (TA), their maximum rate of rise $\left(\mathrm{d}\left[\mathrm{Ca}^{2+}\right]_{i} / \mathrm{d} t_{\max }\right)$, their duration measured at 20,50 , and $90 \%$ decay $\left(\mathrm{TD}_{20}, \mathrm{TD}_{50}\right.$, and $\mathrm{TD}_{90}$, resp.), and their frequency. Parameter values obtained from 10 consecutive $\left[\mathrm{Ca}^{2+}\right]_{i}$ transients were averaged.

2.3. Action Potential Measurements. Action potentials from rabbit and human SAN cells were recorded with 
the amphotericin-perforated and conventional whole-cell configuration of the patch-clamp technique, respectively, using an Axopatch 200B patch-clamp amplifier (Molecular Devices Corporation, Sunnyvale, CA, USA). For recording from rabbit SAN cells, pipettes (borosilicate glass; resistance 2-5 $\mathrm{M} \Omega$ ) were filled with solution containing (in $\mathrm{mM}$ ) K-gluconate 120, $\mathrm{KCl} 20, \mathrm{NaCl} 5$, amphotericin B 0.22, NMDGCl (N-methyl-D-glucammonium chloride) 10, and HEPES 10; $\mathrm{pH}$ was set to 7.2 with $\mathrm{KOH}$. For recording from human SAN cells, patch pipettes contained (in $\mathrm{mM}$ ) K-gluconate 125, $\mathrm{KCl} 20, \mathrm{NaCl} 5, \mathrm{MgCl}_{2} 1, \mathrm{MgATP} 5$, and HEPES 10; $\mathrm{pH}$ was set to 7.2 with $\mathrm{KOH}$.

Action potentials were characterized by their frequency, their duration at 20,50, and $90 \%$ repolarization $\left(\mathrm{APD}_{20}, \mathrm{APD}_{50}\right.$, and $\mathrm{APD}_{90}$, resp. $)$, maximum diastolic potential (MDP), action potential amplitude (APA), maximum upstroke velocity $\left(\mathrm{d} V_{m} / \mathrm{d} t_{\max }\right)$, and diastolic depolarization rate measured over the $100 \mathrm{~ms}$ time interval starting at $\mathrm{MDP}+1 \mathrm{mV}\left(\mathrm{DDR}_{100}\right)$. Parameter values obtained from 10 consecutive action potentials were averaged. All membrane potential values were corrected for the calculated liquid junction potential.

\subsection{Numerical Reconstruction of Hyperpolarization-Activated} Current. For the numerical reconstruction of both rabbit and human $I_{f}$, we used a first-order Hodgkin and Huxley [24] type kinetic scheme. Accordingly, $I_{f}$ is given by

$$
I_{f}=y \times g_{f} \times\left(V_{m}-E_{f}\right),
$$

in which $g_{f}$ is the fully activated $I_{f}$ conductance, $V_{m}$ is the membrane potential, $E_{f}$ is the $I_{f}$ reversal potential, and the gating variable $y$, with $0 \leq y \leq 1$, obeys the first-order differential equation

$$
\frac{\mathrm{d} y}{\mathrm{~d} t}=\alpha \times(1-y)-\beta \times y,
$$

with voltage-dependent rate constants $\alpha$ and $\beta$, or, equivalently,

$$
\frac{\mathrm{d} y}{\mathrm{~d} t}=\frac{\left(y_{\infty}-y\right)}{\tau},
$$

with the steady-state activation $y_{\infty}$ and time constant $\tau$ given by

$$
\begin{aligned}
& y_{\infty}=\frac{\alpha}{(\alpha+\beta)}, \\
& \tau=\frac{1}{(\alpha+\beta)} .
\end{aligned}
$$

For rabbit $I_{f}$, we used the model by Dokos et al. [25], who based their equations on the comprehensive experimental study on rabbit $I_{f}$ by van Ginneken and Giles [26], arriving at

$$
\begin{aligned}
& \alpha=\frac{0.36 \times\left(V_{m}+137.8\right)}{\left\{\exp \left[0.066 \times\left(V_{m}+137.8\right)\right]-1\right\}}, \\
& \beta=\frac{0.1 \times\left(V_{m}+76.3\right)}{\left\{1-\exp \left[-0.21 \times\left(V_{m}+76.3\right)\right]\right\}},
\end{aligned}
$$

for the rate constants $\alpha$ and $\beta$, both expressed in $s^{-1}$. In our computations, we used a scaling factor of 0.71665 for the time constant $\tau$ (5) as a correction factor for the temperature of $30-$ $33^{\circ} \mathrm{C}$ in the experiments of van Ginneken and Giles [26]. This correction factor was adopted from the SAN cell models by Kurata et al. [27] and Maltsev and Lakatta [28]. With the bath and pipette $\mathrm{Na}^{+}$and $\mathrm{K}^{+}$concentrations listed in Sections 2.1 and 2.3, the reversal potential of the Dokos et al. [25] model amounts to $-21.0 \mathrm{mV}$. For the fully activated $I_{f}$ conductance, we used a value of $0.218 \mathrm{pS} / \mathrm{pF}$, based on the mean values of $12.0 \mathrm{nS}$ and $55 \mathrm{pF}$ for the fully activated conductance and membrane capacitance, respectively, reported by van Ginneken and Giles [26].

For human $I_{f}$, we used the model that we developed on the basis of our voltage clamp data on human SAN cells [9]. In this model $[29,30], y_{\infty}$ and $\tau$ (in ms) are given by

$$
\begin{gathered}
y_{\infty}=0.01329+\frac{0.99921}{\left\{1+\exp \left[\left(V_{m}+97.134\right) / 8.1752\right]\right\}} \\
\quad \text { if } V_{m}<-80 \mathrm{mV}, \quad \text { (7) } \\
y_{\infty}=0.0002501 \times \exp \left(\frac{-V_{m}}{12.861}\right) \quad \text { if } V_{m} \geq-80 \mathrm{mV}, \\
\quad \times \frac{\left(V_{m}+148.8\right)}{\left[\exp \left(0.066 \times\left(V_{m}+148.8\right)\right)-1\right]}+0.1 \\
\left.\times \frac{\left(V_{m}+87.3\right)}{\left[1-\exp \left(-0.21 \times\left(V_{m}+87.3\right)\right)\right]}\right\}^{-1}-54
\end{gathered}
$$

respectively. The fully activated $I_{f}$ conductance $g_{f}$ and the $I_{f}$ reversal potential $E_{f}$ were set to $0.075 \mathrm{nS} / \mathrm{pF}$ and $-22 \mathrm{mV}$, respectively, in accordance with the fully activated $I_{f}$ conductance of $75.2 \pm 3.8 \mathrm{pS} / \mathrm{pF}($ mean \pm SEM, $n=3)$ and $I_{f}$ reversal potential of $-22.1 \mathrm{mV} \pm 2.4 \mathrm{mV}$ (mean \pm SEM, $n=3$ ) determined experimentally [9].

The numerical reconstruction was carried out on an Intel Xeon based workstation using Compaq Visual Fortran 6.6C and employing a simple and efficient Euler-type integration scheme with a time step of $10 \mu \mathrm{s}$. Simulations were run for a sufficiently long time to achieve steady-state conditions.

2.5. Numerical Reconstruction of Sodium-Calcium Exchange Current. For the numerical reconstruction of human $I_{\mathrm{NaCa}}$ on the basis of the recorded data on $V_{m}$ and $\left[\mathrm{Ca}^{2+}\right]_{i}(\mathrm{com}-$ bined voltage and calcium clamp [31]), we adopted the $I_{\mathrm{NaCa}}$ formulation of the Courtemanche et al. [20] model for a human atrial myocyte, with $I_{\mathrm{NaCa}}$ scaled down to $74 \%$ of its control value. We thus followed the approach by Chandler et al. [8] in their construction of a mathematical model of a human SAN cell by modification of the Courtemanche et al. [20] model, as set out in the Introduction.

We used a similar approach for the numerical reconstruction of rabbit $I_{\mathrm{NaCa}}$ on the basis of the acquired data on $V_{m}$ 
and $\left[\mathrm{Ca}^{2+}\right]_{i}$. In this case, we adopted the $I_{\mathrm{NaCa}}$ formulation of the Lindblad et al. [32] model for a rabbit atrial myocyte. However, the original $I_{\mathrm{NaCa}}$ was scaled down to $78 \%$ of its control value, based on the mRNA data by Allah et al. [21], as detailed in the Introduction.

The Courtemanche et al. [20] and Lindblad et al. [32] equations not only require values for $V_{m}$ and $\left[\mathrm{Ca}^{2+}\right]_{i}$, but also for $\left[\mathrm{Ca}^{2+}\right]_{e},\left[\mathrm{Na}^{+}\right]_{e}$ and $\left[\mathrm{Na}^{+}\right]_{i}$, which denote the extracellular $\mathrm{Ca}^{2+}$ concentration, the extracellular $\mathrm{Na}^{+}$concentration, and the intracellular $\mathrm{Na}^{+}$concentration, respectively. For these ion concentrations, we used the bath and pipette solutions listed in Sections 2.1 and 2.3.

2.6. Statistics. Data are presented as mean \pm SEM. Comparisons between groups were made using an unpaired $t$-test. The level of significance was set at $P<0.05$.

\section{Results}

For the present study, we first characterized the action potentials and $\left[\mathrm{Ca}^{2+}\right]_{i}$ transients that we recorded from single rabbit and human SAN pacemaker cells. Next, we used our experimental data for a numerical reconstruction of the hyperpolarization-activated current and the sodiumcalcium exchange current associated with the recorded action potentials and $\left[\mathrm{Ca}^{2+}\right]_{i}$ transients, thus allowing a comparison of these currents between rabbit and human SAN pacemaker cells.

3.1. Rabbit and Human Action Potentials. Figure 1(a) shows typical examples of the spontaneous action potentials of rabbit and human SAN pacemaker cells, recorded with the patch-clamp technique. Maximum diastolic potential (MDP) and action potential amplitude (APA) are remarkably similar, whereas the beating frequency is strikingly different, as confirmed by the mean value of $3.11 \pm 0.24 \mathrm{~Hz}$ for the 7 rabbit cells versus $1.21 \pm 0.02 \mathrm{~Hz}$ for the 3 human cells $(P<0.05)$ and illustrated in Figure 1(b).

Neither the action potential durations, for example, the $\mathrm{APD}_{90}$ of $144 \pm 35$ versus $113 \pm 6 \mathrm{~ms}$, nor the diastolic depolarization rate of $49 \pm 18$ versus $89 \pm 19 \mathrm{mV} / \mathrm{s}$ differ significantly between human and rabbit SAN cells, which is likely due to the low number of cells of human origin. Nevertheless, from Figure 1(a), it is indicative that the longer cycle length of the human cells ( $828 \pm 15$ versus $337 \pm 35 \mathrm{~ms}$ ) is importantly due to longer diastolic depolarization rather than longer action potential duration. A further difference is found in the maximum rate of rise of the action potential, which is considerably larger in the rabbit cells $(13.0 \pm 1.6$ versus $4.6 \pm 1.2 \mathrm{~V} / \mathrm{s}, P<0.05$; Figure $1(\mathrm{~b})$ ).

3.2. Rabbit and Human $\left[\mathrm{Ca}^{2+}\right]_{i}$ Transients. In the 7 rabbit cells of Figure 1(b), we simultaneously recorded the membrane potential, using the perforated patch-clamp technique, and the $\left[\mathrm{Ca}^{2+}\right]_{i}$ transient, using the fluorescent $\mathrm{Ca}^{2+}$ indicator Indo-1. A typical example of such $\left[\mathrm{Ca}^{2+}\right]_{i}$ transient, recorded from the same cell and during the same period of time as used for Figure 1(a), is provided in Figure 1(c). Also shown in Figure $1(\mathrm{c})$ is the $\left[\mathrm{Ca}^{2+}\right]_{i}$ transient that we were able to record from a single human SAN cell. Further attempts to acquire the $\left[\mathrm{Ca}^{2+}\right]_{i}$ transient of human cells resulted in unstable recordings. Of note, no action potentials are available from the cell that we recorded the $\left[\mathrm{Ca}^{2+}\right]_{i}$ transient from. So, in contrast with the rabbit data, the human data of Figures 1(a) and 1 (c) are not simultaneously collected and are not from the same cell.

The minimum diastolic $\left[\mathrm{Ca}^{2+}\right]_{i}$ level of the human cell is similar to that of the rabbit cells, but otherwise the $\left[\mathrm{Ca}^{2+}\right]_{i}$ transients are widely different, with a smaller amplitude, longer duration, and smaller rate of rise in case of the human cell, as illustrated in Figure 1(d), in which the characteristics of the $\left[\mathrm{Ca}^{2+}\right]_{i}$ transient of the human cell are compared to those of the mean characteristics in the 7 rabbit cells.

As illustrated in Figure 2(a) for the simultaneously recorded action potential (top) and $\left[\mathrm{Ca}^{2+}\right]_{i}$ transient (bottom) of a rabbit SAN cell, the maximum rate of rise of the $\left[\mathrm{Ca}^{2+}\right]_{i}$ transient, as determined from the time derivative of the $\left[\mathrm{Ca}^{2+}\right]_{i}$ transient signal (Figure 2(b), bottom), occurs with a time lag relative to the maximum rate of rise of the associated action potential, as determined from the time derivative of the $V_{m}$ signal (Figure 2(b), top). This time lag between the occurrence of $\mathrm{d} V_{m} / \mathrm{d} t_{\max }$ and $\mathrm{d}\left[\mathrm{Ca}^{2+}\right]_{i} / \mathrm{d} t_{\max }$ was determined for each of the 7 rabbit SAN cells tested and amounted to $21.3 \pm 0.6 \mathrm{~ms}$. The time lag ranged between 19 and $23 \mathrm{~ms}$ and showed no appreciable frequency dependence, as illustrated in Figure 2(c), in which the time lag is plotted versus the spontaneous beating frequency.

3.3. Numerical Reconstruction of Membrane Ionic Currents. Next, we carried out a numerical reconstruction of the hyperpolarization-activated current $\left(I_{f}\right)$ and the sodiumcalcium exchange current $\left(I_{\mathrm{NaCa}}\right)$ of rabbit and human SAN pacemaker cells based on the experimental data on their action potentials and $\left[\mathrm{Ca}^{2+}\right]_{i}$ transients presented in Figures 1 and 2 .

3.3.1. Experimental Data. For the reconstruction of rabbit membrane ionic currents, we used a 1-s simultaneous recording of $V_{m}$ and $\left[\mathrm{Ca}^{2+}\right]_{i}$ of one of the 7 rabbit cells that we digitized at $10 \mathrm{kHz}$ through linear interpolation of the acquired data points. This 1-s recording contained three action potentials and associated $\left[\mathrm{Ca}^{2+}\right]_{i}$ transients and was turned into a continuous signal by repeating the 1-s signal. Because of the repetition of the 1-s signal, the fourth and fifth action potentials of Figure 3(a) (left) are identical to the first and second, respectively. The same holds for the associated $\left[\mathrm{Ca}^{2+}\right]_{i}$ transients, which are shown in Figure 3(b) (left).

A similar approach, now using a $\approx 1.6 \mathrm{~s}$ time frame, was used in case of the human cell data. However, because data on $V_{m}$ and $\left[\mathrm{Ca}^{2+}\right]_{i}$ were not simultaneously collected, we selected two consecutive action potentials with cycle lengths of 791 and 822 ms-human SAN pacemaker cells show a beat-tobeat fluctuation in cycle length as do rabbit cells [33] - and two consecutive $\left[\mathrm{Ca}^{2+}\right]_{i}$ transients that, by coincidence, had identical cycle lengths. Furthermore, for the timing of the two signals, it was assumed that the time lag between the occurrence of $\mathrm{d} V_{m} / \mathrm{d} t_{\max }$ and $\mathrm{d}\left[\mathrm{Ca}^{2+}\right]_{i} / \mathrm{d} t_{\max }$ was $21 \mathrm{~ms}$, as 


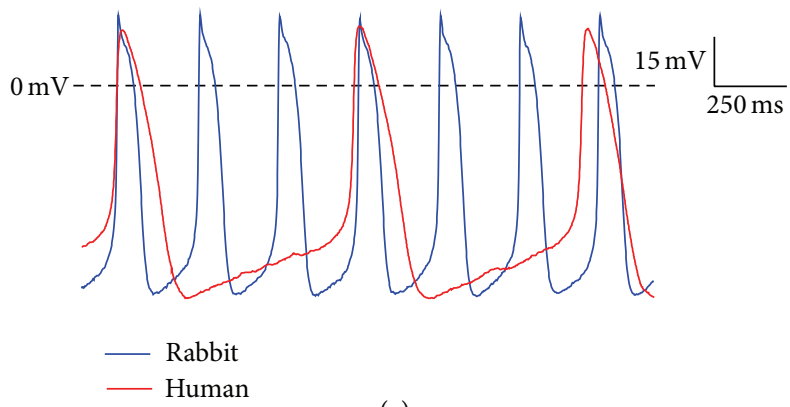

(a)

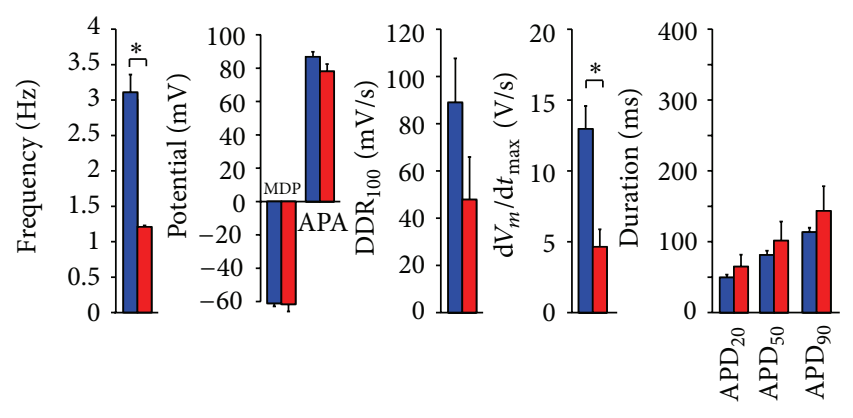

Rabbit $(n=7)$

Human $(n=3)$

(b)

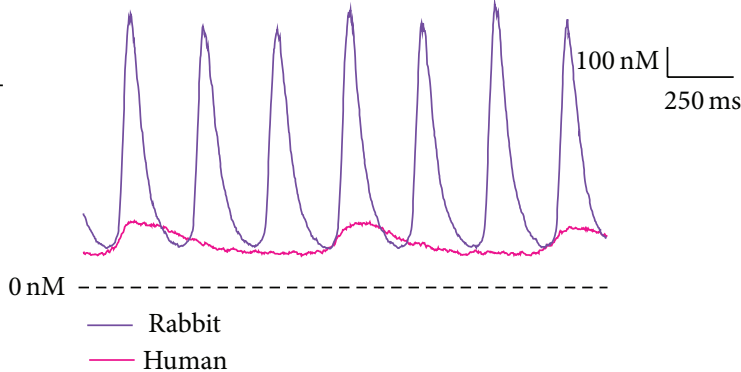

(c)

FIGURE 1: Spontaneous electrical activity of rabbit and human sinoatrial node (SAN) pacemaker cells. (a) and (b) Typical examples (a) and average characteristics (b) of action potentials. (c) and (d) Typical examples (c) and average characteristics (d) of the intracellular free Ca ${ }^{2+}$ concentration $\left(\left[\mathrm{Ca}^{2+}\right]_{i}\right)$. Data are mean $\pm \mathrm{SEM} ; n=$ number of cells; MDP = maximum diastolic potential; APA = action potential amplitude; $\mathrm{DDR}_{100}=$ diastolic depolarization rate over the $100 \mathrm{~ms}$ time interval starting at $\mathrm{MDP}+1 \mathrm{mV} ; \mathrm{d} V_{m} / \mathrm{d} t_{\max }=$ maximal upstroke velocity; $\mathrm{APD}_{20}, \mathrm{APD}_{50}$, and $\mathrm{APD}_{90}=$ action potential duration at 20,50 , and $90 \%$ repolarization; $\mathrm{MDC}=$ minimum diastolic $\left[\mathrm{Ca}^{2+}\right]_{i} ; \mathrm{TA}=\left[\mathrm{Ca}{ }^{2+}\right]_{i}$ transient amplitude; $\mathrm{d}\left[\mathrm{Ca}^{2+}\right]_{i} / \mathrm{d} t_{\max }=$ maximum rate of rise of $\left[\mathrm{Ca}^{2+}\right]_{i}$ transient; $\mathrm{TD}_{20}, \mathrm{TD}_{50}$, and $\mathrm{TD} 90=\left[\mathrm{Ca}^{2+}\right]_{i}$ transient duration at 20 , 50 , and $90 \%$ decay. ${ }^{*} P<0.05$.

observed in the rabbit cells (Figure $2(\mathrm{c})$ ). The resulting $V_{m}$ and $\left[\mathrm{Ca}^{2+}\right]_{i}$ data are shown in the right panels of Figures $3(\mathrm{a})$ and $3(\mathrm{~b})$.

\subsubsection{Numerical Reconstruction of Net Membrane Current.} As a reference for $I_{f}$ and $I_{\mathrm{NaCa}}$, we first determined the net membrane current $\left(I_{\text {net }}\right)$ in both rabbit and human cells. Because $I_{\text {net }}=-C_{m} \times \mathrm{d} V_{m} / \mathrm{d} t$, where $C_{m}$ denotes membrane capacitance, the current density of $I_{\text {net }}$ is identical to $-\mathrm{d} V_{m} / \mathrm{d} t$ and thus readily follows from the time derivative of the action potential, which is shown in Figure 3(c) for the action potentials of Figure 3(a). In the diastolic voltage range, $I_{\text {net }}$ is a small inward current with a density of $\approx 0.1$ and $\approx 0.05 \mathrm{pA} / \mathrm{pF}$ in rabbit and human, respectively (Figures 3(d) and 3(e), gray traces), in line with the mean diastolic depolarization rate of $89 \pm 19$ and $49 \pm 18 \mathrm{mV} / \mathrm{s}$, respectively (Figure 1(b)). Figure 3(c) also confirms the data of Figure 1(b) regarding the smaller $\mathrm{d} V_{m} / \mathrm{d} t_{\max }$ in human versus rabbit SAN cells.

3.3.3. Numerical Reconstruction of HyperpolarizationActivated Current. The action potentials of Figure 3(a) were applied as a voltage clamp signal in order to reconstruct the hyperpolarization-activated current $I_{f}$, as detailed in Section 2.4. The resulting $I_{f}$ traces are shown in Figure 3(d).
There is an almost 7-fold difference in diastolic $I_{f}$ amplitude between rabbit and human, which becomes less pronounced when compared to the net membrane current, $I_{\text {net }}$, in each of the cell types. In rabbit, diastolic $I_{f}$ is 2-3 times $I_{\text {net }}$, whereas diastolic $I_{f}$ and $I_{\text {net }}$ are of similar size in human.

\subsubsection{Numerical Reconstruction of Sodium-Calcium Exchange} Current. The $V_{m}$ and $\left[\mathrm{Ca}^{2+}\right]_{i}$ data of Figures 3(a) and 3(b) were applied as a combined voltage and calcium clamp signal in order to reconstruct the sodium-calcium exchange current $I_{\mathrm{NaCa}}$ in human and rabbit SAN cells, as detailed in Section 2.5. The resulting $I_{\mathrm{NaCa}}$ is smaller in amplitude in human than in rabbit (Figure 3(e)). However, in either case, the mid-diastolic $I_{\mathrm{NaCa}}$ amplitude is roughly twice that of $I_{\text {net }}$. The end-diastolic amplitude of $I_{\mathrm{NaCa}}$ at $-45 \mathrm{mV}$ is $\approx 0.07 \mathrm{pA} / \mathrm{pF}$ in human, which is $\approx 25 \%$ of the value of $\approx$ $0.28 \mathrm{pA} / \mathrm{pF}$ in rabbit.

3.3.5. Charge Carried by Individual Currents. From the current traces of Figures 3(d) and 3(e), one can compute the contribution to diastolic depolarization in terms of charge carried by $I_{\text {net }}$, $I_{f}$, and $I_{\mathrm{NaCa}}$ through integration of each of these currents over time. We carried out such computation for the $20 \mathrm{mV}$ spontaneous depolarization from $\mathrm{MDP}+1 \mathrm{mV}$ 


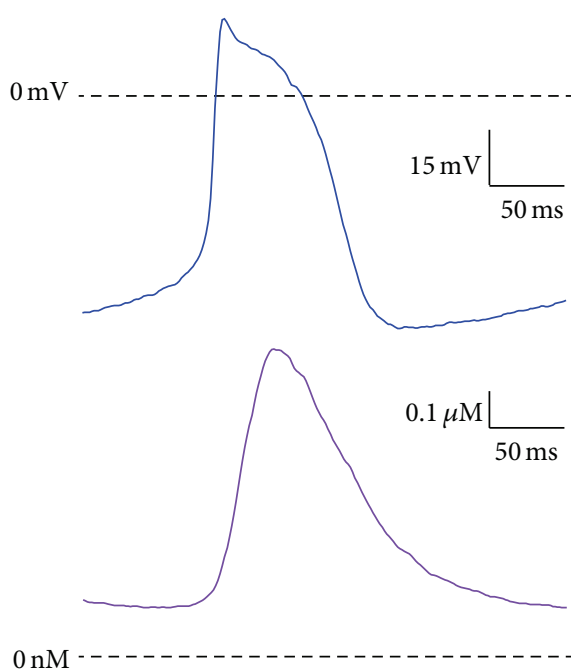

(a)

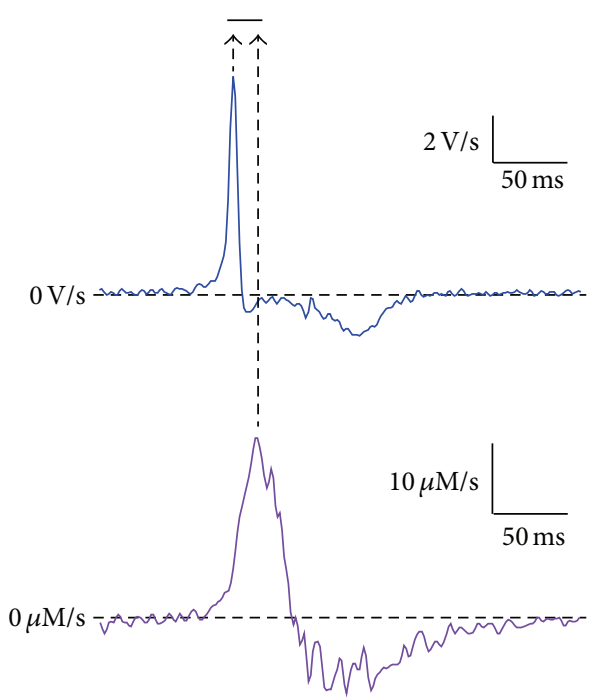

(b)

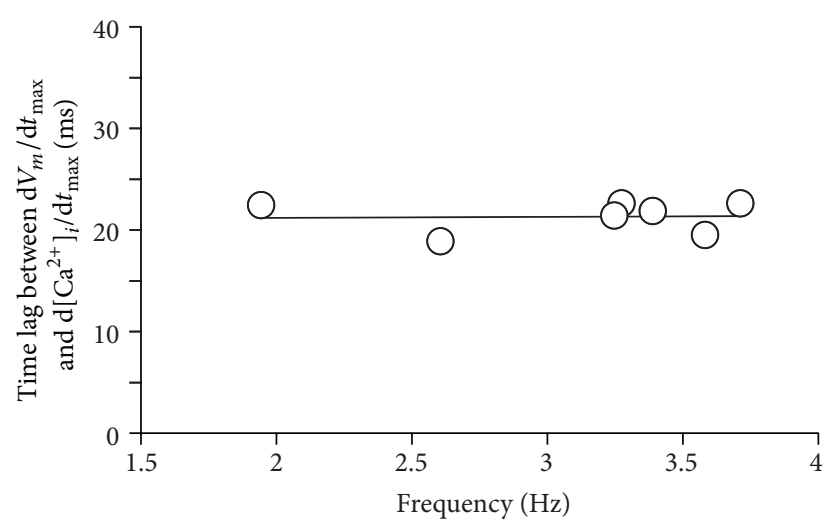

(c)

Figure 2: (a), Simultaneously recorded action potential (top) and $\left[\mathrm{Ca}^{2+}\right]_{i}$ transient (bottom) of a rabbit SAN cell. (b) Time derivatives of the action potential (top) and $\left[\mathrm{Ca}^{2+}\right]_{i}$ transient (bottom) traces shown in panel (a). Arrows indicate the timing of the maximum rate of change in membrane potential $\left(\mathrm{d} V_{m} / \mathrm{d} t_{\max }\right)$ and intracellular $\mathrm{Ca}^{2+}$ concentration $\left(\mathrm{d}\left[\mathrm{Ca}^{2+}\right]_{i} / \mathrm{d} t_{\max }\right)$. Horizontal bar indicates the time lag of $\approx 20 \mathrm{~ms}$. (c) Time lag between the occurrence of $\mathrm{d} V_{m} / \mathrm{d} t_{\max }$ and $\mathrm{d}\left[\mathrm{Ca}^{2+}\right]_{i} / \mathrm{d} t_{\max }$ versus beating frequency of the 7 cells measured. Solid line is the linear regression line (slope $0.1 \pm 1.1 ; R=0.042$ ). Note the absence of an appreciable frequency dependence of the time lag.

of the rabbit and human action potentials of Figure 3(a). As shown in Figure 4 (left bars), the thus computed charge carried by $I_{\text {net }}\left(Q_{\text {net }}\right)$ amounts to $0.020 \mathrm{pC} / \mathrm{pF}$ for both rabbit and human, as expected from the $20 \mathrm{mV}$ depolarization, which is equivalent to a charge flow of $0.02 \mathrm{pC} / \mathrm{pF}$. The charge carried by $I_{f}\left(Q_{f}\right)$ is 0.043 and $0.018 \mathrm{pC} / \mathrm{pF}$ for rabbit and human, respectively, whereas that carried by $I_{\mathrm{NaCa}}\left(Q_{\mathrm{NaCa}}\right)$ amounts to 0.055 and $0.047 \mathrm{pC} / \mathrm{pF}$, respectively (Figure 4, middle and right bars).

\section{Discussion}

In the present study, we first characterized the action potentials and $\left[\mathrm{Ca}^{2+}\right]_{i}$ transients that we recorded from single rabbit and human SAN pacemaker cells. Next, we used our experimental data for a numerical reconstruction of the hyperpolarization-activated current and the sodiumcalcium exchange current associated with the recorded action potentials and $\left[\mathrm{Ca}^{2+}\right]_{i}$ transients.

4.1. Experimental Data. Human SAN pacemaker cells have a lower beating frequency and a lower maximum upstroke velocity than rabbit SAN pacemaker cells (Figures 1(a) and 1(b)). Also, they have a considerably weaker $\left[\mathrm{Ca}^{2+}\right]_{i}$ transient (Figures 1(c) and 1(d)), which may, at least in part, be a frequency effect, as observed in rabbit cells [23]. The longer cycle length of the human cells is largely due to a longer diastolic phase (Figures 1(a) and 1(b)). In this respect, the recorded action potentials differ from those that Chandler et al. [8] computed by turning the Courtemanche et al. [20] human atrial cell model into a human SAN pacemaker cell model. On the other hand, the range of the computed calcium 

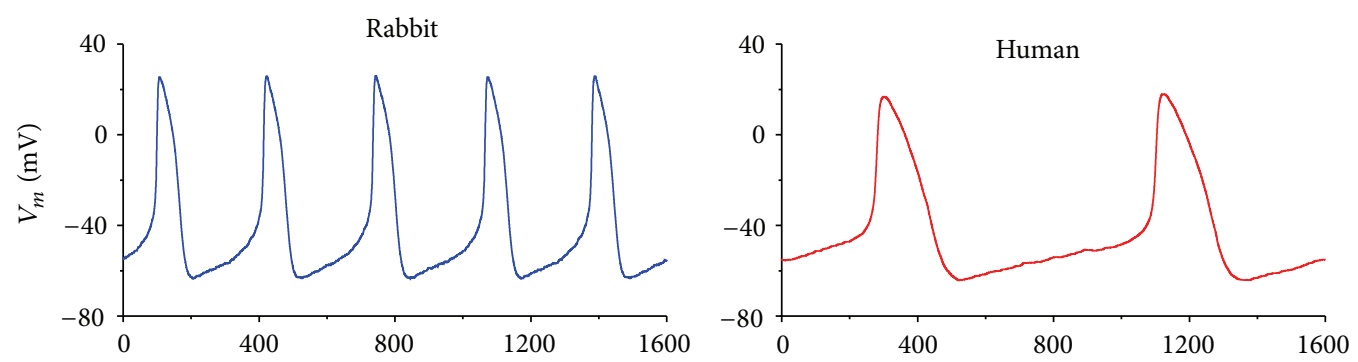

(a)
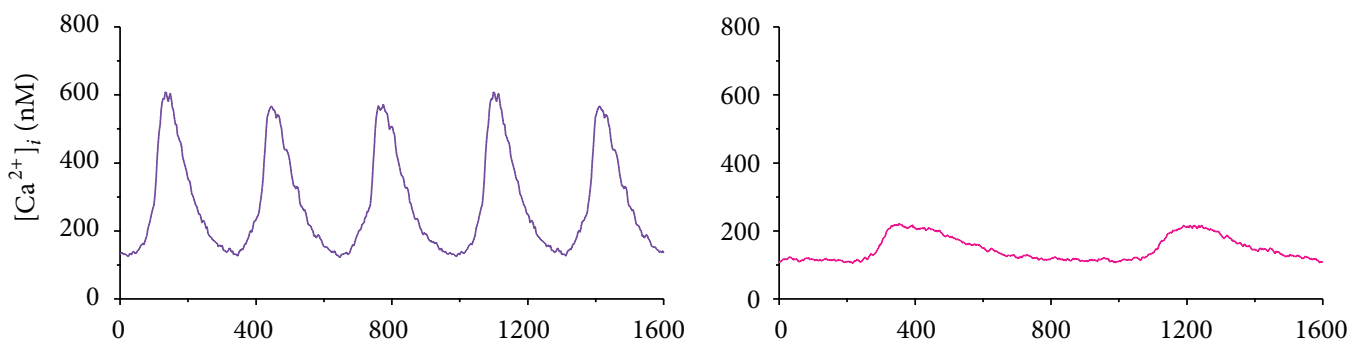

(b)
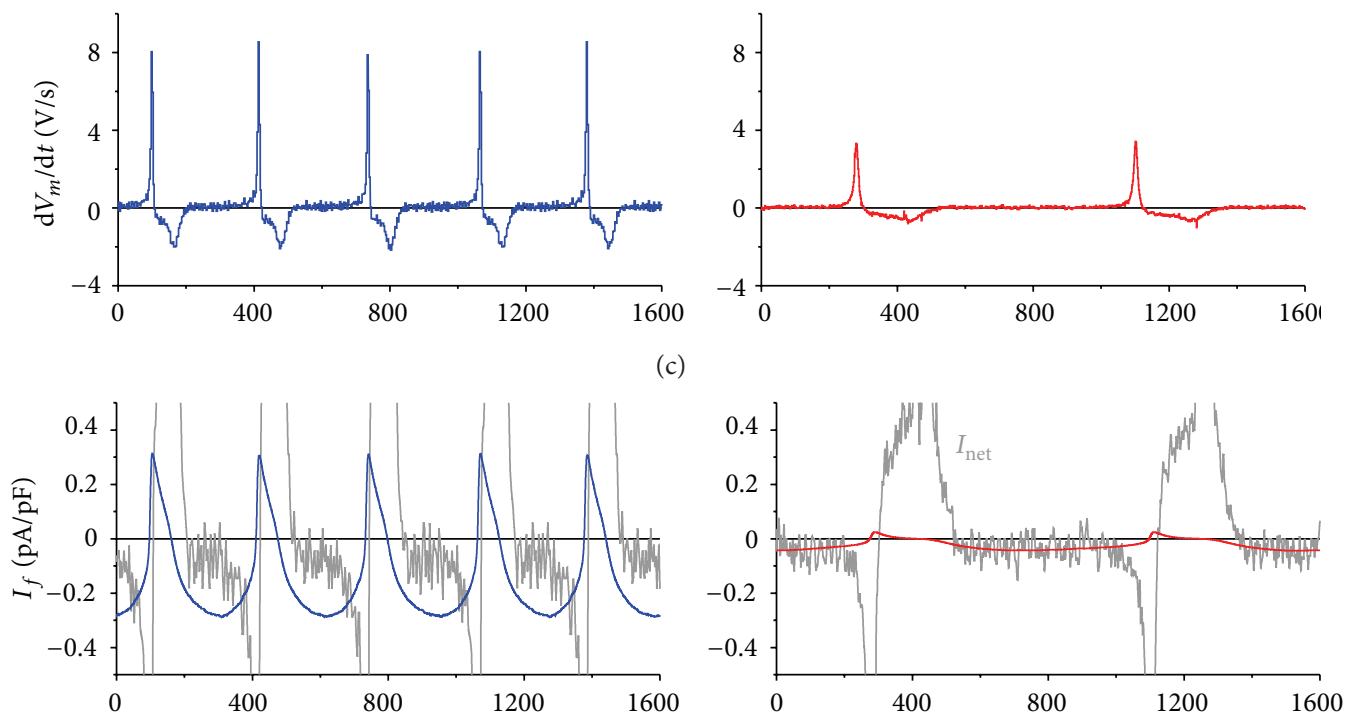

(d)
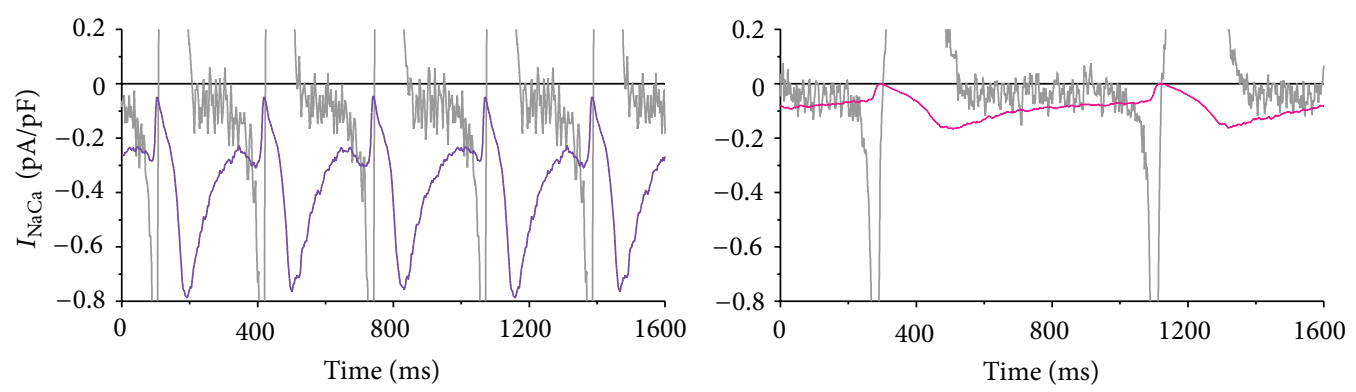

(e)

FIGURE 3: Action potential and calcium transient recordings from rabbit (left) and human (right) SA nodal myocytes and associated numerical reconstructions of membrane currents. (a) Recorded membrane potential $V_{m}$. (b) Recorded intracellular calcium concentration $\left(\left[\mathrm{Ca}^{2+}\right]_{i}\right)$. (c) Time derivative of $V_{m}\left(\mathrm{~d} V_{m} / \mathrm{d} t\right)$. (d) Reconstructed hyperpolarization-activated inward current $\left(I_{f}\right)$. The noisy trace in gray is the net membrane current $\left(I_{\text {net }}\right)$ computed from $I_{\text {net }}=-C_{m} \times \mathrm{d} V_{m} / \mathrm{d} t$, where $C_{m}$ denotes membrane capacitance. (e) Reconstructed sodium-calcium exchange current $\left(I_{\mathrm{NaCa}}\right)$, with the net membrane current in gray. 


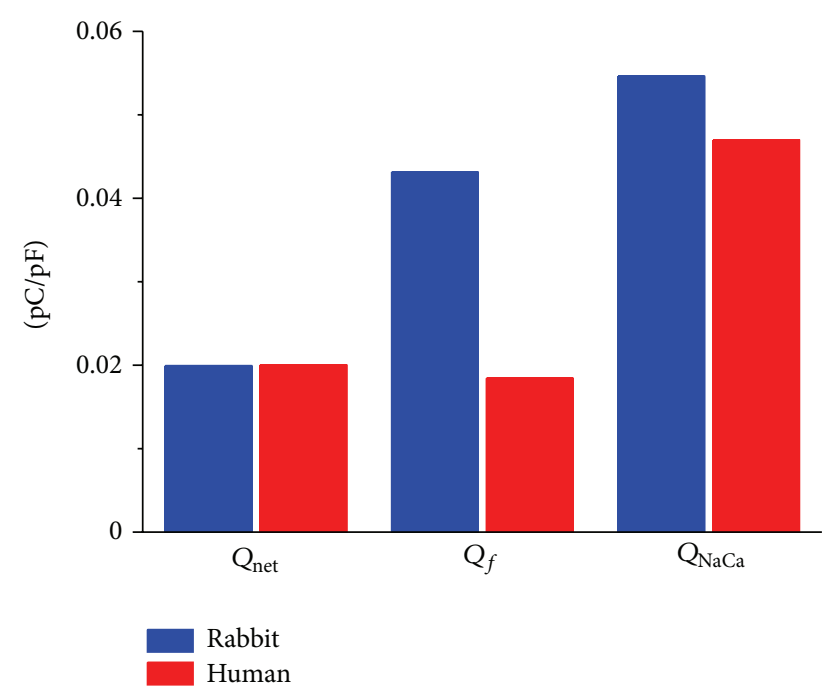

FIGURE 4: Charge carried by net membrane current $\left(Q_{\text {net }}\right)$, reconstructed hyperpolarization-activated inward current $\left(Q_{f}\right)$, and reconstructed sodium-calcium exchange current $\left(Q_{\mathrm{NaCa}}\right)$ during $20 \mathrm{mV}$ spontaneous depolarization from MDP $+1 \mathrm{mV}$ of the rabbit and human SA nodal action potentials of Figure 3.

signal (approximately 150-250 nM; Figure 8 of Chandler et al. [8]) compares reasonably well with the experimentally observed range (roughly 110-220 nM; Figures 1(c) and 1(d)).

As an important caveat, it should be noted that our data on human cells have been collected from only a small number of cells, all from a single patient who underwent SAN excision because of tachycardias [9]. Stable action potential recordings were obtained from three cells and a stable calcium transient recording from only one cell. Furthermore, although almost identical experimental methods were employed, the use of the perforated-patch configuration of the patch-clamp technique in case of the rabbit cells and the conventional whole-cell configuration in case of the human cells may have introduced deviations.

4.2. Numerical Reconstructions. In our numerical reconstruction of rabbit $I_{f}$, we used the Dokos et al. [25] equations based on a reanalysis of the data by van Ginneken and Giles [26] rather than the equations provided by van Ginneken and Giles [26] themselves. In the latter equations, the $I_{f}$ deactivation rate is erroneously overestimated, as set out in detail by Dokos et al. [25]. As a result, the reconstructed $I_{f}$ of Figure 3(d) (left) is larger than in rabbit SAN cell models that employ the van Ginneken and Giles equations, such as the models by Kurata et al. [27] and Maltsev and Lakatta [28]. Furthermore, the more negative maximum diastolic potential of the recorded action potentials adds to the larger $I_{f}$. The availability of $I_{f}$ almost immediately after repolarization and its amplitude larger than that of $I_{\text {net }}$ are in line with the data from action potential clamp experiments on rabbit SAN cells carried out by Zaza et al. [34]. The reconstructed human $I_{f}$ trace compares well with the traces that we previously reconstructed for the other two human SAN pacemaker cells from which action potentials are available [12].
In our numerical reconstruction of $I_{\mathrm{NaCa}}$, we used equations from rabbit and human atrial cell models-properly scaled to account for the reduced mRNA expression of NCX1 in the SAN versus the atrium, both in human [8] and in rabbit [21] - that allowed the reconstruction of $I_{\mathrm{NaCa}}$ from the experimentally recorded membrane potential and global cytosolic $\left[\mathrm{Ca}^{2+}\right]_{i}$. Today, there are highly detailed models of calcium handling in (rabbit) SAN cells [28, 35], but for a reconstruction of $I_{\mathrm{NaCa}}$, these would require experimental data on $\left[\mathrm{Ca}^{2+}\right]_{i}$ in submembrane spaces rather than global cytosolic $\left[\mathrm{Ca}^{2+}\right]_{i}$. In human cells, the total charge carried by $I_{f}$ during spontaneous diastolic depolarization is similar to that carried by $I_{\text {net }}$, whereas in rabbit it is approximately twice (Figure 4).

Of note, the diastolic $I_{\mathrm{NaCa}}$ amplitude at $-45 \mathrm{mV}$ of $\approx 0.28 \mathrm{pA} / \mathrm{pF}$ in rabbit (Figure $3(\mathrm{e}$ ), left) is identical to the value of $0.28 \pm 0.03 \mathrm{pA} / \mathrm{pF}$ that Vinogradova et al. [36] observed experimentally. A highly similar amplitude is obtained (data not shown) if $I_{\mathrm{NaCa}}$ is not reconstructed from the Lindblad et al. [32] equations but from the equations for a ventricular cell provided by Faber and Rudy [37], scaled down to $69 \%$ to account for the mRNA data by Allah et al. [21].

Human $I_{\mathrm{NaCa}}$ is smaller than that of rabbit (Figure 3(e)). This is not only due to the smaller $I_{\mathrm{NaCa}}$ in the human versus the rabbit atrial cell model from which the equations were adopted for the reconstruction. What also plays a role is that the experimentally recorded $\left[\mathrm{Ca}^{2+}\right]_{i}$ is smaller in human than in rabbit at all values of $V_{m}$. Yet, the total charge carried by $I_{\mathrm{NaCa}}$ during spontaneous diastolic depolarization is of similar magnitude in rabbit and human (Figure 4).

\section{Conclusion}

Human SAN pacemaker cells have a smaller $I_{f}$, a weaker $\left[\mathrm{Ca}^{2+}\right]_{i}$ transient, and a smaller $I_{\mathrm{NaCa}}$ than rabbit SAN pacemaker cells. However, when compared to the diastolic net membrane current, $I_{\mathrm{NaCa}}$ is of similar size in human and rabbit cells, whereas $I_{f}$ is smaller in human than in rabbit cells.

\section{Conflict of Interests}

The authors declare that they have no conflict of interests.

\section{References}

[1] M. E. Mangoni and J. Nargeot, "Genesis and regulation of the heart automaticity," Physiological Reviews, vol. 88, no. 3, pp. 919982, 2008.

[2] E. G. Lakatta, V. A. Maltsev, and T. M. Vinogradova, "A Coupled SYSTEM of intracellular $\mathrm{Ca}^{2+}$ clocks and surface membrane voltage clocks controls the timekeeping mechanism of the heart's pacemaker," Circulation Research, vol. 106, no. 4, pp. 659$673,2010$.

[3] E. G. Lakatta and D. DiFrancesco, "What keeps us ticking: a funny current, a calcium clock, or both?" Journal of Molecular and Cellular Cardiology, vol. 47, no. 2, pp. 157-170, 2009. 
[4] D. DiFrancesco and D. Noble, "The funny current has a major pacemaking role in the sinus node," Heart Rhythm, vol. 9, no. 2, pp. 299-301, 2012.

[5] V. A. Maltsev and E. G. Lakatta, "The funny current in the context of the coupled-clock pacemaker cell system," Heart Rhythm, vol. 9, no. 2, pp. 302-307, 2012.

[6] D. DiFrancesco and D. Noble, "Rebuttal: The funny current in the context of the coupled clock pacemaker cell system," Heart Rhythm, vol. 9, no. 3, pp. 457-458, 2012.

[7] E. G. Lakatta and V. A. Maltsev, "Rebuttal: what $\mathrm{I}_{f}$ the shoe doesn't fit? The funny current has a major pacemaking role in the sinus node," Heart Rhythm, vol. 9, no. 3, pp. 459-460, 2012.

[8] N. J. Chandler, I. D. Greener, J. O. Tellez et al., "Molecular architecture of the human sinus node insights into the function of the cardiac pacemaker," Circulation, vol. 119, no. 12, pp. 1562$1575,2009$.

[9] A. O. Verkerk, R. Wilders, M. M. G. J. van Borren et al., "Pacemaker current $\left(I_{f}\right)$ in the human sinoatrial node," European Heart Journal, vol. 28, no. 20, pp. 2472-2478, 2007.

[10] A. O. Verkerk, R. Wilders, M. M. G. J. van Borren, and H. L. Tan, "Is sodium current present in human sinoatrial node cells?" International Journal of Biological Sciences, vol. 5, no. 2, pp. 201204, 2009.

[11] H. Dobrzynski, M. R. Boyett, and R. H. Anderson, "New insights into pacemaker activity: promoting understanding of sick sinus syndrome," Circulation, vol. 115, no. 14, pp. 1921-1932, 2007.

[12] A. O. Verkerk, A. C. G. van Ginneken, and R. Wilders, "Pacemaker activity of the human sinoatrial node: role of the hyperpolarization-activated current, $I_{f}$," International Journal of Cardiology, vol. 132, no. 3, pp. 318-336, 2009.

[13] W. Zareba, A. J. Moss, P. J. Schwartz et al., "Influence of the genotype on the clinical course of the long-QT syndrome," The New England Journal of Medicine, vol. 339, no. 14, pp. 960-965, 1998.

[14] H. Swan, M. Viitasalo, K. Piippo, P. Laitinen, K. Kontula, and L. Toivonen, "Sinus node function and ventricular repolarization during exercise stress test in long QT syndrome patients with KVLQT1 and HERG potassium channel defects," Journal of the American College of Cardiology, vol. 34, no. 3, pp. 823-829, 1999.

[15] A. Leenhardt, I. Denjoy, and P. Guicheney, "Catecholaminergic polymorphic ventricular tachycardia," Circulation Arrhythmia and Electrophysiology, vol. 5, no. 5, pp. 1044-1052, 2012.

[16] A. Leenhardt, V. Lucet, I. Denjoy, F. Grau, Dien Do Ngoc, and P. Coumel, "Catecholaminergic polymorphic ventricular tachycardia in children: a 7-year follow-up of 21 patients," Circulation, vol. 91, no. 5, pp. 1512-1519, 1995.

[17] N. Sumitomo, K. Harada, M. Nagashima et al., "Catecholaminergic polymorphic ventricular tachycardia: electrocardiographic characteristics and optimal therapeutic strategies to prevent sudden death," Heart, vol. 89, no. 1, pp. 66-70, 2003.

[18] A. V. Postma, I. Denjoy, T. M. Hoorntje et al., "Absence of calsequestrin 2 causes severe forms of catecholaminergic polymorphic ventricular tachycardia," Circulation Research, vol. 91, no. 8, pp. e21-e26, 2002.

[19] A. V. Postma, I. Denjoy, J. Kamblock et al., "Catecholaminergic polymorphic ventricular tachycardia: RYR2 mutations, bradycardia, and follow up of the patients," Journal of Medical Genetics, vol. 42, no. 11, pp. 863-870, 2005.

[20] M. Courtemanche, R. J. Ramirez, and S. Nattel, "Ionic mechanisms underlying human atrial action potential properties: insights from a mathematical model," American Journal of Physiology, vol. 275, no. 1, pp. H301-H321, 1998.

[21] E. A. Allah, J. O. Tellez, J. Yanni et al., "Changes in the expression of ion channels, connexins and $\mathrm{Ca}^{2+}$-handling proteins in the sino-atrial node during postnatal development," Experimental Physiology, vol. 96, no. 4, pp. 426-438, 2011.

[22] A. O. Verkerk, H. M. den Ruijter, J. Bourier et al., "Dietary fish oil reduces pacemaker current and heart rate in rabbit," Heart Rhythm, vol. 6, no. 10, pp. 1485-1492, 2009.

[23] M. M. G. J. van Borren, A. O. Verkerk, R. Wilders et al., "Effects of muscarinic receptor stimulation on $\mathrm{Ca}^{2+}$ transient, cAMP production and pacemaker frequency of rabbit sinoatrial node cells," Basic Research in Cardiology, vol. 105, no. 1, pp. 73-87, 2010.

[24] A. L. Hodgkin and A. F. Huxley, "A quantitative description of membrane current and its application to conduction and excitation in nerve," The Journal of Physiology, vol. 117, no. 4, pp. 500-544, 1952.

[25] S. Dokos, B. Celler, and N. Lovell, "Ion currents underlying sinoatrial node pacemaker activity: a new single cell mathematical model," Journal of Theoretical Biology, vol. 181, no. 3, pp. 245272, 1996.

[26] A. C. G. van Ginneken and W. Giles, "Voltage clamp measurements of the hyperpolarization-activated inward current $I_{f}$ in single cells from rabbit sino-atrial node," Journal of Physiology, vol. 434 , pp. 57-83, 1991.

[27] Y. Kurata, I. Hisatome, S. Imanishi, and T. Shibamoto, "Dynamical description of sinoatrial node pacemaking: improved mathematical model for primary pacemaker cell," American Journal of Physiology Heart and Circulatory Physiology, vol. 283, no. 5, pp. H2074-H2101, 2002.

[28] V. A. Maltsev and E. G. Lakatta, "Synergism of coupled subsarcolemmal $\mathrm{Ca}^{2+}$ clocks and sarcolemmal voltage clocks confers robust and flexible pacemaker function in a novel pacemaker cell model," American Journal of Physiology Heart and Circulatory Physiology, vol. 296, no. 3, pp. H594-H615, 2009.

[29] A. O. Verkerk, M. M. G. J. van Borren, R. J. G. Peters et al., "Single cells isolated from human sinoatrial node: action potentials and numerical reconstruction of pacemaker current," in Proceedings of the 29th Annual International Conference of Engineering in Medicine and Biology Society (EMBC '07), pp. 904-907, August 2007.

[30] A. O. Verkerk and R. Wilders, "Relative importance of funny current in human versus rabbit sinoatrial node," Journal of Molecular and Cellular Cardiology, vol. 48, no. 4, pp. 799-801, 2010.

[31] M. M. G. J. van Borren, J. G. Zegers, A. O. Verkerk, and R. Wilders, "Computational model of rabbit SA node pacemaker activity probed with action potential and calcium transient clamp," in Proceedings of the 29th Annual International Conference of Engineering in Medicine and Biology Society (EMBC'07), pp. 156-159, August 2007.

[32] D. S. Lindblad, C. R. Murphey, J. W. Clark, and W. R. Giles, "A model of the action potential and underlying membrane currents in a rabbit atrial cell," American Journal of Physiology, vol. 271, no. 4, part 2, pp. H1666-H1696, 1996.

[33] R. Wilders and H. J. Jongsma, "Beating irregularity of single pacemaker cells isolated from the rabbit sinoatrial node," Biophysical Journal, vol. 65, no. 6, pp. 2601-2613, 1993. 
[34] A. Zaza, M. Micheletti, A. Brioschi, and M. Rocchetti, "Ionic currents during sustained pacemaker activity in rabbit sinoatrial myocytes," Journal of Physiology, vol. 505, no. 3, pp. 677688, 1997.

[35] M. S. Imtiaz, P. Y. von der Weid, D. R. Laver, and D. F. van Helden, "SR Ca ${ }^{2+}$ store refill-a key factor in cardiac pacemaking," Journal of Molecular and Cellular Cardiology, vol. 49, no. 3, pp. 412-426, 2010.

[36] T. M. Vinogradova, S. Sirenko, A. E. Lyashkov et al., "Constitutive phosphodiesterase activity restricts spontaneous beating rate of cardiac pacemaker cells by suppressing local $\mathrm{Ca}^{2+}$ releases," Circulation Research, vol. 102, no. 7, pp. 761-769, 2008.

[37] G. M. Faber and Y. Rudy, "Action potential and contractility changes $\left[\mathrm{Na}^{+}\right]_{\mathrm{i}}$ in overloaded cardiac myocytes: a simulation study," Biophysical Journal, vol. 78, no. 5, pp. 2392-2404, 2000. 

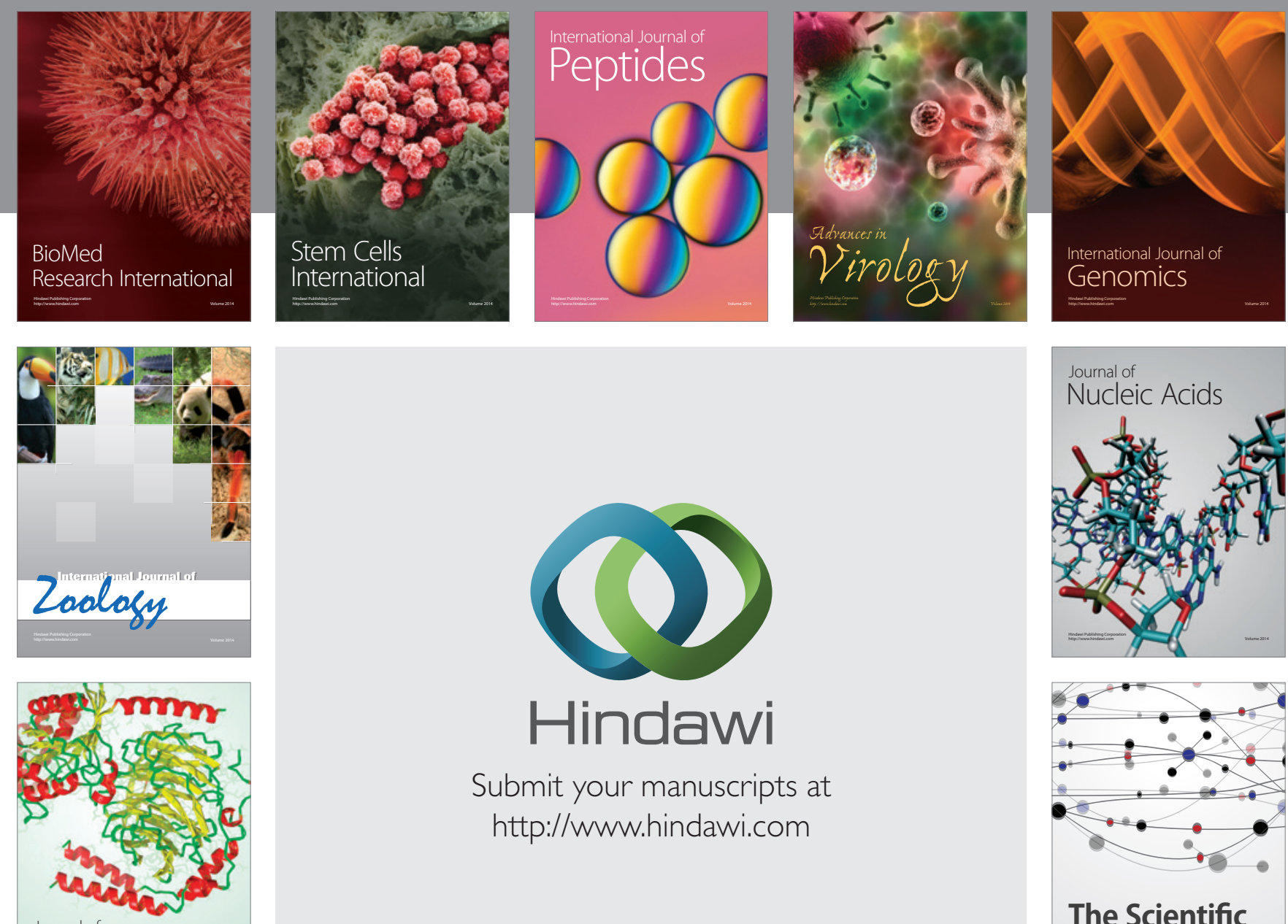

Submit your manuscripts at

http://www.hindawi.com

Journal of
Signal Transduction
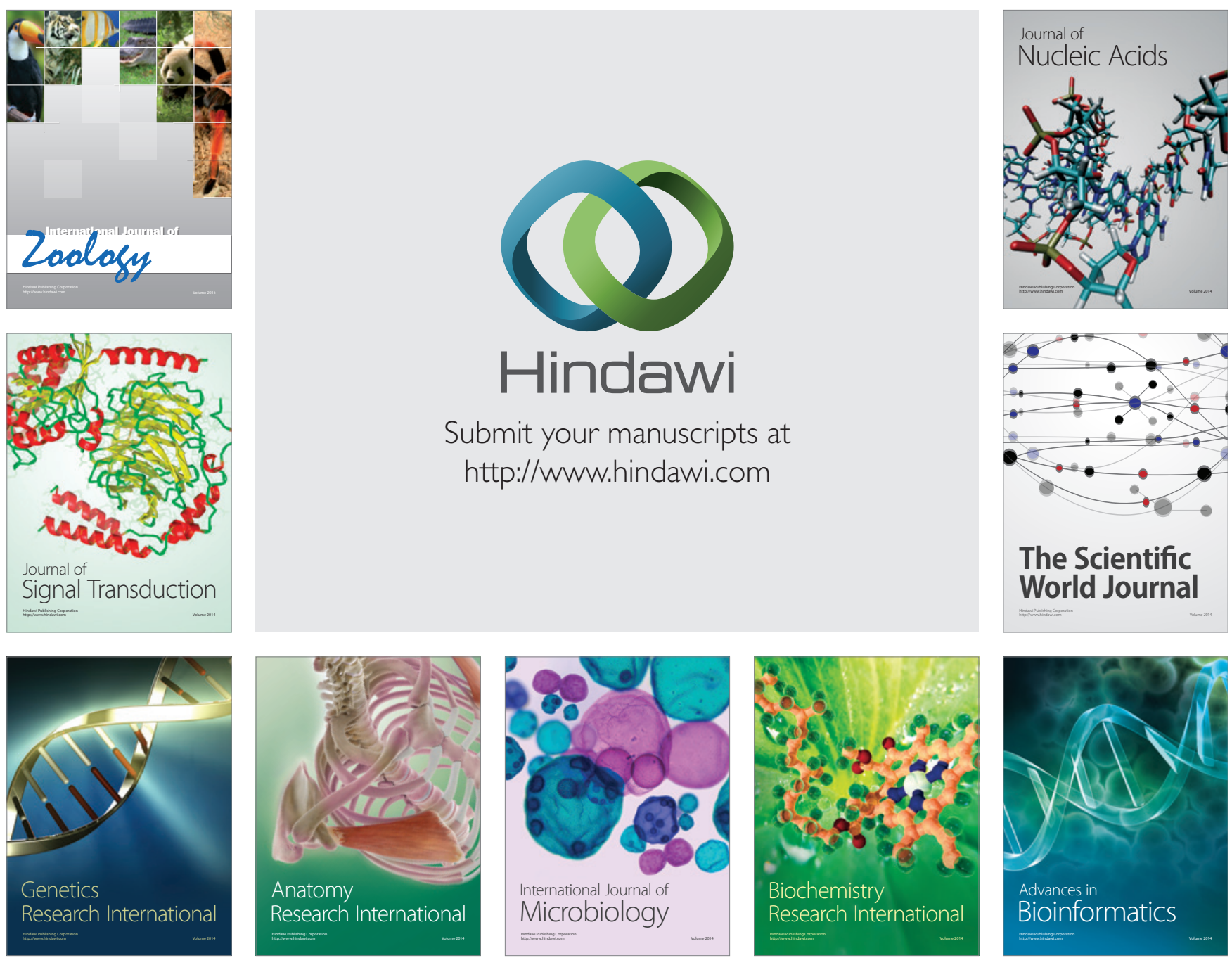

The Scientific World Journal
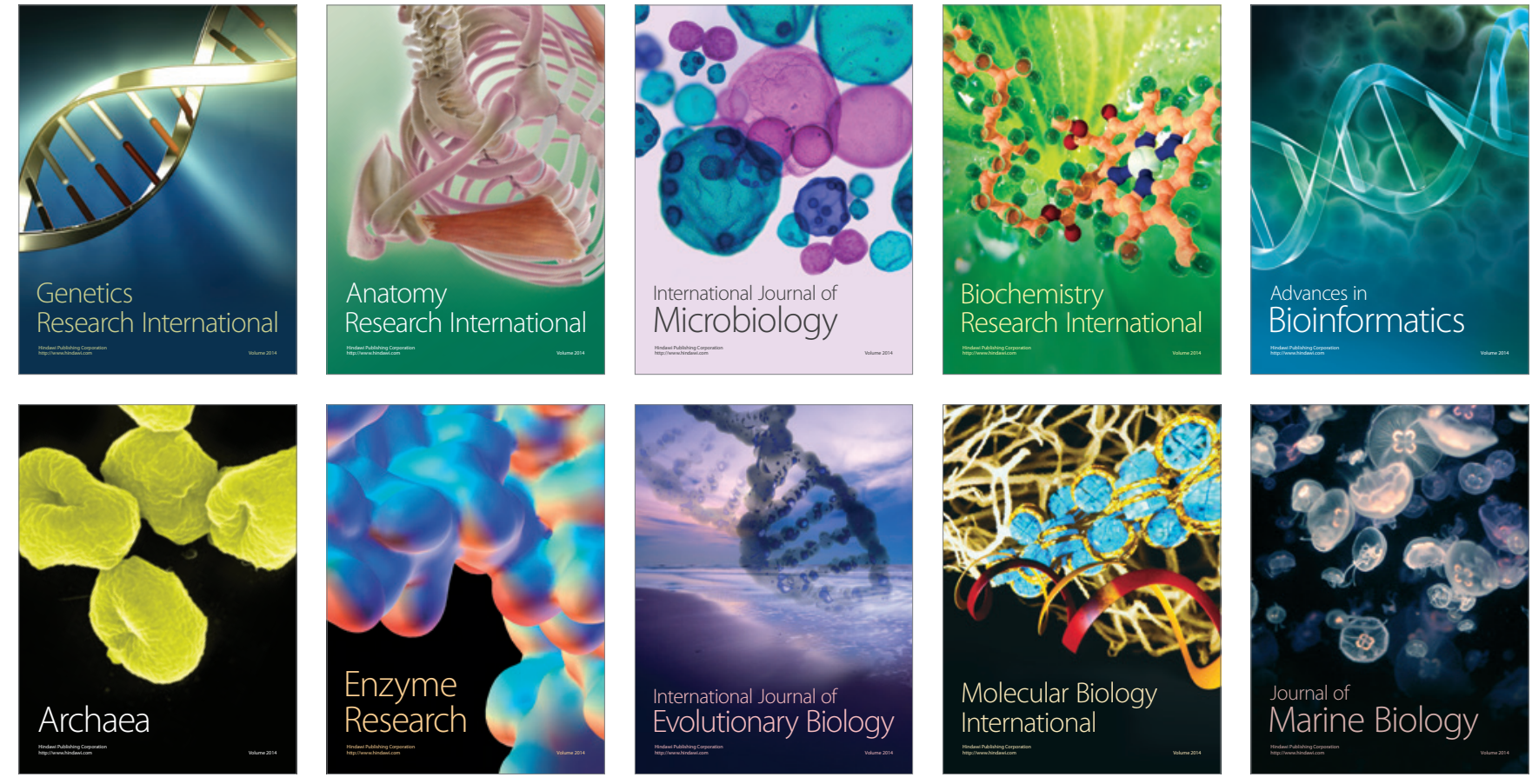